\title{
P. A. Gunchenko ${ }^{1}$, L. V. Chernish ${ }^{1}$, E. Yu. Tikhonchuk ${ }^{1}$, J. Becker ${ }^{2}$,
}

P. R. Schreiner ${ }^{2}$, A. A. Fokin ${ }^{1,2}$

${ }^{1}$ National Technical University of Ukraine "Igor Sikorsky Kyiv Polytechnic Institute"

37, Peremohy Ave., Kyiv, 03056, Ukraine. E-mail: pag@xtf.kpi.ua

2 Justus Liebig University Giessen, Germany

\section{Functionalization of diamantane dimers}

Aim. To develop preparative methods for functionalization of diamantane dimers.

Results and discussion. The reaction of 1,1'-bisdiamantane with bromine and the subsequent hydrolysis gives 6-hydroxy-1,1'-bisdiamantane with a yield of 56\%. The reactions of 4,4'-bisdiamantane with nitric acid or liquid bromine followed by hydrolysis leads to a mixture of hydroxy derivatives and 1,1'-dihydroxy-4,4'-bisdiamantane after isomerization in sulfuric acid (with a yield of $73 \%$ ). Thus, the reactivity of bisdiamantanes with electrophiles is determined by the higher stability of the carbocations in the medial positions of the cages as shown by DFT computations. Whereas medial bridgehead substitutions dominate in reactions of 4,4'-bisdiamantane with electrophiles, the arylation with benzene in the presence of tert-butyl bromide and aluminum chloride gives bis-apical derivative - 9,9'-diphenyl-4,4'-bisdiamantane.

Experimental part. The structure of 6 -hydroxy-1,1'-bisdiamantane was confirmed by X-ray diffraction analysis. The substitution pattern in 1,1'-dihydroxy-4,4'-bisdamantane was confirmed by 2D-NMR spectra. The arylation of 4,4'-bisdiamantane with benzene proceeds as bis-apical substitution to give highly symmetric 9,9'-diphenyl-4,4'-bisdiamantane in $47 \%$.

Conclusions. It has been shown that the medial bridgehead substitution dominates in the reactions of bisdiamantanes with strong electrophiles, and only the arylation of 4,4'-bisdiamantane proceeds as a bis-apical substitution.

Key words: diamantane dimers; halogenation; nitroxylation; phenylation

П. О. Гунченко ${ }^{1}$, Л. В. Черниш ${ }^{1}$, Є. Ю. Тихончук ${ }^{1}$, Д. Бекер ${ }^{2}$, П. Р. Шрайнер ${ }^{2}$,

А. А. Фокін ${ }^{1,2}$

${ }^{1}$ НТУУ «Київський політехнічний інститут імені Ігоря Сікорського», Україна

2 Гіссенський університет імені Юстуса Лібіха, Німеччина

Функціоналізація димерів діамантану

Мета. Розробити препаративні методи функціоналізації димерів діамантану.

Результати та їх обговорення. Реакція 1,1'-бісдіамантану з бромом і подальший гідроліз дають 6-гідрокси1,1'-бісдіамантан з виходом 56\%. Реакція 4,4'-бісдіамантану з азотною кислотою або рідким бромом з наступним гідролізом приводить до суміші гідроксипохідних та до 1,1'-дигідрокси-4,4'-бісдіамантану після ізомеризації в сірчаній кислоті (вихід - 73\%). Таким чином, реакційна здатність бісдіамантанів з електрофрілами визначається більшою стабільністю карбокатіонів у медіальних положеннях каркасів, що було доведено DFT-розрахунками. Тоді як медіальне заміщення домінує в реакціях 4,4'-бісдамантану з електрофілами, арилювання бензеном у присутності mpem-бутилброміду та алюмінію хлориду дає біс-апікальне похідне 9,9'-дифеніл-4,4'-бісдіамантан.

Експериментальна частина. Структуру 6-гідрокси-1,1'-бісдіамантану було доведено даними рентгеноструктурного аналізу. Напрямок заміщення в 1,1'-дигідрокси-4,4'-бісдіамантані було підтверджено спектрами 2D-яМP. Арилювання 4,4'-бісдіамантану бензеном відбувається як біс-апікальне заміщення 3 утворенням 9,9'-дифеніл-4,4'-бісдіамантану з виходом $47 \%$.

Висновки. Показано, що медіальне заміщення домінує в реакціях бісдіамантанів із сильними електрофрілами, і лише арилювання 4,4'-бісдіамантану перебігає як біс-апікальне заміщення.

Ключові слова: димери діамантану; галогенування; нітроксилювання; фенілювання

П. А. Гунченко ${ }^{1}$, Л. В. Черныш ${ }^{1}$, Е. Ю. Тихончук , Д. Бэкер², П. Р. Шрайнер²,

А. А. Фокин ${ }^{1,2}$

${ }_{1}^{1}$ НТУУ «Киевский политехнический институт имени Игоря Сикорского», Украина

${ }^{2}$ Гиссенский университет имени Юстуса Либиха, Германия

Функционализация димеров диамантана

Цель. Разработать препаративные методы функционализации димеров диамантана.

Результаты и их обсуждение. Реакция 1,1'-бисдиамантана с бромом и последующий гидролиз дают 6-гидрокси-1,1'-бисдиамантан с выходом 56\%. Реакция 4,4'-бисдиамантана с азотной кислотой или жидким бромом с последующим гидролизом приводит к смеси гидроксипроизводных и 1,1'-дигидрокси4,4'-бисдиамантана после изомеризации в серной кислоте (выход - 73\%). Таким образом, реакционная способность бис-диамантанов с электрофилами обусловлена большей стабильностью карбкатионов в медиальных положениях, что было подтверждено DFT-расчетами. Тогда как медиальное замещение доминирует в реакциях 4,4'-бисдиамантана с электрофилами, арилирование бензолом в присутствии $m p e m$ бутилбромида и хлорида алюминия дает бис-апикальное производное 9,9'-дифенил-4,4'-бисдиамантан.

Экспериментальная часть. Структура 6-гидрокси-1,1'-бисдиамантана была подтверждена данными рентгеноструктурного анализа. Направление замещения в 1,1'-дигидрокси-4,4'-бисдиамантане было подтверждено спектрами 2D-ЯMP. Арилирование 4,4'-бисдиамантана бензолом протекает как бис-апикальное замещение с образованием высокосимметричного 9,9'-дифенил-4,4'-бисдиамантана с выходом $47 \%$.

Выводы. Показано, что медиальное замещение доминирует в реакциях бисдиамантанов с сильными электрофилами, и только арилирование 4,4'-бисдиамантана протекает как бис-апикальное замещение.

Ключевые слова: димеры диамантана; галогенирование; нитроксилирование; фенилирование 
The combination of strength, rigidity [1,2], electron emission, and unique optical properties make diamond materials particularly attractive for nanotechnology [3]. The applications of nanodiamond materials obtained through chemical vapor deposition (CVD, films thicker than $3 \mathrm{~nm}$ ) [4] and detonation (particles larger than $2 \mathrm{~nm}$ ) [5] techniques are hampered by the inhomogeneity of the materials formed [6]. Physically and chemically homogeneous diamondoids, which are hydrocarbons that resemble parts of the diamond lattice, are seen as alternatives to industrial nanodiamond [7] as their higher representatives are able to mimic some key electronic properties of diamond [8]. While the lower diamondoids (adamantane, diamantane, and triamantane) are common in natural oil and were extracted in kilogram to ton quantities [9], the isolation of higher diamondoids starting from tetramantane is cumbersome since they exist as mixtures of isomers [9, 10]. Alternatively, large diamondoid particles may be constructed by coupling of lower diamondoids [11], and thus obtained dimers, such as 1,1'-bisdiamantane $\mathbf{1}$ [12], 4,4'-bisdiamantane 2 [13], and 1,1'-bisadamantane 3 [14], not only reach the dimensions of higher diamondoids, but also resemble the parts of the diamond lattice themselves (Fig. 1).

Most of the practical applications of diamondoids require functionalization, e. g., the incorporation of surface attachment points [15] allowing to construct diamond-like self-assembled monolayers (SAMs) [16, $17,18]$. The aim of this work is to derivatize $\mathbf{1}$ and $\mathbf{2}$ in order to provide an opportunity for practical applications of this class of readily available hydrocarbons.

In contrast to highly symmetric parent 3 , whose mono- and bis-derivatives are readily available [14, $19,20]$, selective functionalization of $C_{2}$-symmetric 1 and $D_{3 \mathrm{~d}}$-symmetric 2 is challenging as seven $(\mathbf{A}-\mathbf{F})$ and three $(\mathbf{A}-\mathbf{C})$ nonequivalent tertiary $\mathrm{CH}-$ positions are present in their structures (Fig. 2). Note that the apical derivatives (C and D) are more attractive since they are characterized by higher surface affinities and form more ordered SAMs [18]. Additionally, while the central C-C bond in $\mathbf{2}$ is close to "normal" one, which is typical for alkanes, this bond in 1 is elongated up to $1.647 \AA$ due to severe steric hindrance caused by the 1-diamantyl fragments [21].

While this very long bong is strengthened by attractive London dispersion interactions [22], it still may complicate functionalization of $\mathbf{1}$, especially under single-electron transfer (SET) oxidative conditions. The radical cation $\mathbf{1}^{+}$contains an electron-depleted long (2.414 Å, Fig. 2) central C-C bond [11] that results in a low dissociation energy $\left(24.5 \mathrm{kcal} \cdot \mathrm{mol}^{-1}\right.$, M06-2X/cc-pVDZ [23]) of ionized 1. Indeed, for the SET oxidation of 1 with photoexcited 1,2,4,5-tetracyanobenzene (TCB) in acetonitrile we found 1-acetamidodiamantane as the only diamondoid reaction product.

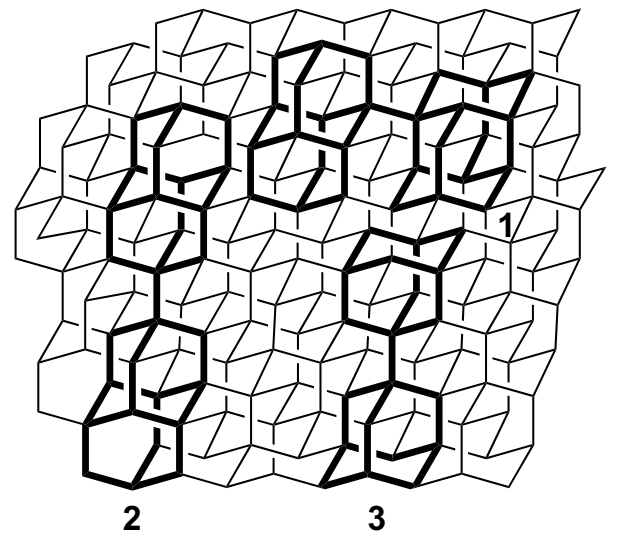

Fig. 1. Diamondoid dimers 1,1'-bisdiamantane 1, 4,4'-bisdiamantane 2, 1,1'-bisadamantane 3 resemble the parts of the diamond lattice

This is in sharp contrast to the oxidation of pristine diamantane that gives exclusively the $\mathrm{C}-\mathrm{H}$ bond substitution product under photooxidation with TCB [24].

The reactions of cage hydrocarbons with electrophiles $\left(\mathrm{E}=\mathrm{Br}_{2}, \mathrm{HNO}_{3}, \mathrm{NO}_{2} \mathrm{NO}_{3}\right)$ proceed as $\mathrm{H}$-coupled electron transfer with strong $\mathrm{C} \bullet \bullet \cdot \mathrm{H} \bullet \bullet \cdot \mathrm{E}$ bonding [25] in the transition structures for hydrogen abstraction. As a result, the substitution selectivity correlates reasonably well with the relative stability of the corresponding tertiary carbocations [26]. The computed relative stabilities of the carbocations derived from $\mathbf{1}$ at M06-2X/cc-pVDZ level of theory show that the nonclassic cations $\mathbf{1 A}$ and $\mathbf{1 B}$ are most stable, but their formation may be hampered by steric hindrance for the attack of electrophile on the endo-hydrogens (Fig. 2). As the medial cations $\mathbf{1 E - G}$ are close in energy and about 3-4 $\mathrm{kcal} \cdot \mathrm{mol}^{-1}$ more stable than the apical cations $1 \mathrm{C}$ and 1D, the predominant formation of the medial derivatives is expected upon the reaction of $\mathbf{1}$ with electrophiles. Accordingly, in the reaction of $\mathbf{1}$ with elementary bromine in $\mathrm{CS}_{2}$ at room temperature we obtained a complex mixture of mono- and disubstituted derivatives, and the subsequent hydrolysis followed by chromatographic separation on silica gel gave the medial alcohol 6-hydroxy-1,1'-bisdiamantane 4 with a yield of $56 \%$. The structure of 4 was confirmed by single crystal X-ray diffraction (Fig. 2) as well as NMR data.

Note that despite the very long (and seemingly reactive) central $\mathrm{C}-\mathrm{C}$ bond in $\mathbf{1}$, no monomeric 1 -diamantyl derivatives were detected in the reaction mixture. This is in contrast to transformations of strained dehydrodiamondoids with electrophiles where $\mathrm{C}-\mathrm{C}$ addition products dominate [27]. Alcohol $\mathbf{4}$ is a useful building block for further functional modifications of diamantane dimers. For instance, amine 7 was prepared through acetamide 6 obtained from 4 by a modified [28] Ritter reaction (Fig. 3).

To functionalize 2 we performed bromination, as well as nitroxylation [29], and obtained a complex mixture of hydroxy derivatives after hydrolysis (Scheme 1). 


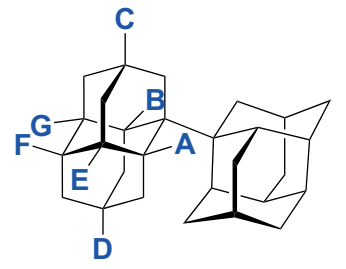

1

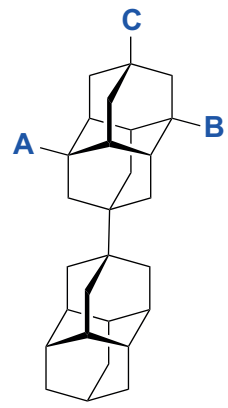

2

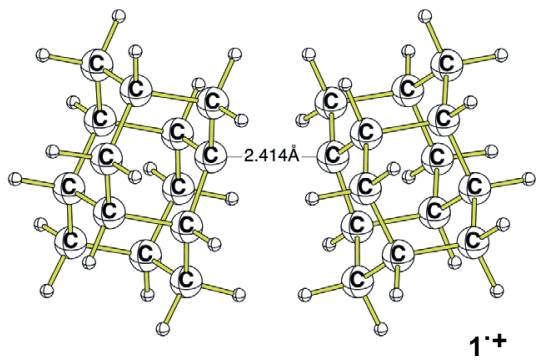

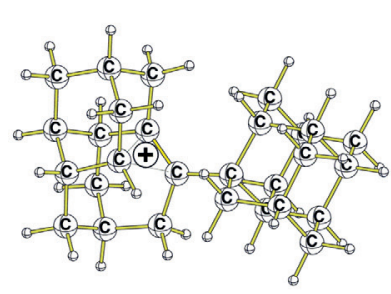

1A 0.0

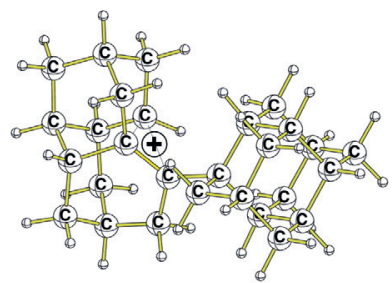

1B $\quad 0.1$

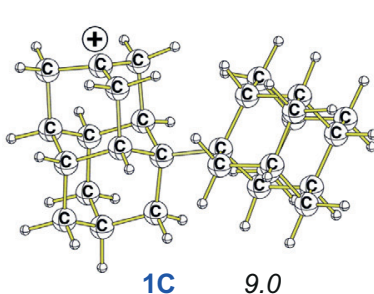

$1 \mathrm{C}$

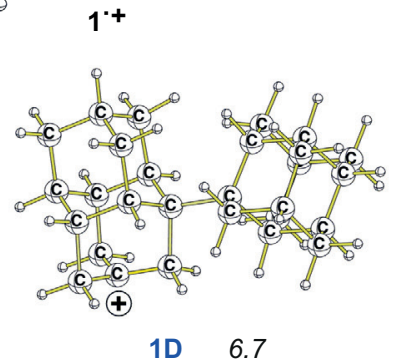

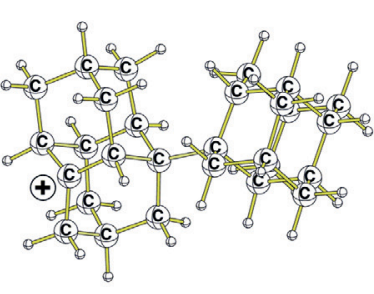

1E $\quad 5.4$

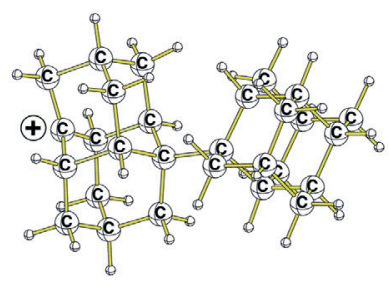

1F 6.4

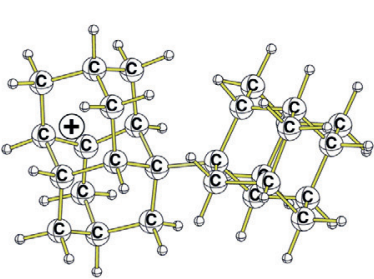

$1 \mathrm{G} \quad 6.4$

medial

Fig. 2. Different tertiary C-H positions in 1,1'-bisdiamantane 1 and 4,4'-bisdiamantane 2, the structure of 1,1'-bisdiamantane radical cation 1.+ and relative enthalpies $\left(\Delta H^{298}, \mathrm{M06}-2 \mathrm{X} / \mathrm{cc}-\mathrm{pVDZ}, \mathrm{kcal} \cdot \mathrm{mol}^{-1}\right.$, italic) of tertiary carbocations derived from 1 (1A-G)

The mixture was isomerized in sulfuric acid, which, in the case of hydroxyl diamantanes, usually results in predominant formation of apical derivatives [30]. However, we observed the formation of bis-medial 1,1'-dihydroxy-4,4'-bisdiamantane 8 as the main product with the yield of ca. $60 \%$ (Scheme 1).

The averaged $C_{2 \mathrm{~h}}$-symmetry of $\mathbf{8}$ was confirmed by the ${ }^{13} \mathrm{C}$ NMR spectrum, involving ten signals, as well as by the DEPT ${ }^{13} \mathrm{C}$ NMR spectrum, where four methyne and four methylene resonances were observed. The position of hydroxy groups was confirmed based on the analysis of the cross-peaks of the $\mathrm{CH}_{2}$-groups in the COSY ${ }^{1} \mathrm{H}$ NMR spectrum of $\mathbf{8}$. The same diol was obtained after the isomerization of a mixture of alcohols derived from the bromination/hydrolysis of $\mathbf{2}$.

Since the most attractive bis-apical derivatives were not obtained under conditions of thermodynamicallycontrolled isomerization of hydroxyl derivatives of $\mathbf{2}$, we performed the Friedel-Crafts arylation of $\mathbf{2}$ with benzene in the presence of the Lewis acid (Scheme 2). This resulted in 9,9'-diphenyl-4,4'-bisdiamantane 9, whose structure was confirmed by the combination of spectral methods.

Thus, apical substitution is possible under thermodynamically controlled direct functionaliza18 tion of $\mathbf{2}$, and thus obtained hydrocarbon $\mathbf{9}$ with averaged $D_{3 \mathrm{~h}}$-symmetry may be seen as a building block for further incorporation of substituents into the axial positions of diamondoid dimers. Various methods previously developed for phenylated diamondoids, namely the oxidation of phenyl to the carboxyl group with $\mathrm{RuCl}_{3} / \mathrm{H}_{5} \mathrm{IO}_{6}$ [31] or the iodination of 4,9-diphenyldiamantane [32] with $\mathrm{CF}_{3} \mathrm{COOI}$ be useful.

\section{Experimental part}

All solvents and reagents used were of analytical grade and obtained from commercial suppliers. ${ }^{1} \mathrm{H}$ and ${ }^{13} \mathrm{C}$ NMR spectra were obtained in $\mathrm{CDCl}_{3}$ on Bruker Avance III 400 and $600 \mathrm{MHz}$ spectrometers (TMS was used as an internal standard). Mass spectra were recorded on a HP 5890 Series II with HP5971A and ESI-MS Bruker Micro-TOF spectrometers.

Bromination/hydrolysis of 1,1'-bisdiamantane 1. To the solution of $0.995 \mathrm{~g}$ ( $2.66 \mathrm{mmol})$ of 1,1'-bisdiamantane in $30 \mathrm{~mL}$ of $\mathrm{CS}_{2}$, dropwise $30 \mathrm{~mL}$ of bromine was added while stirring at $0^{\circ} \mathrm{C}$, and the mixture obtained was stirred additionally for $3 \mathrm{~h}$ at $0^{\circ} \mathrm{C}$. The reaction mixture was diluted with $\mathrm{CHCl}_{3}$, the excess of bromine was quenched with $\mathrm{Na}_{2} \mathrm{SO}_{3}$, the organic layer was washed with water and brine. The aqueous 

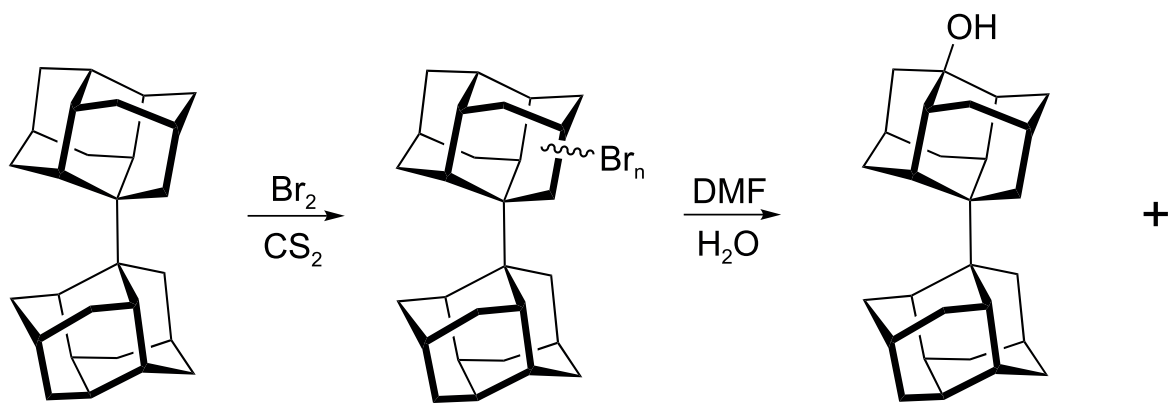

1

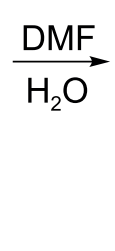

4
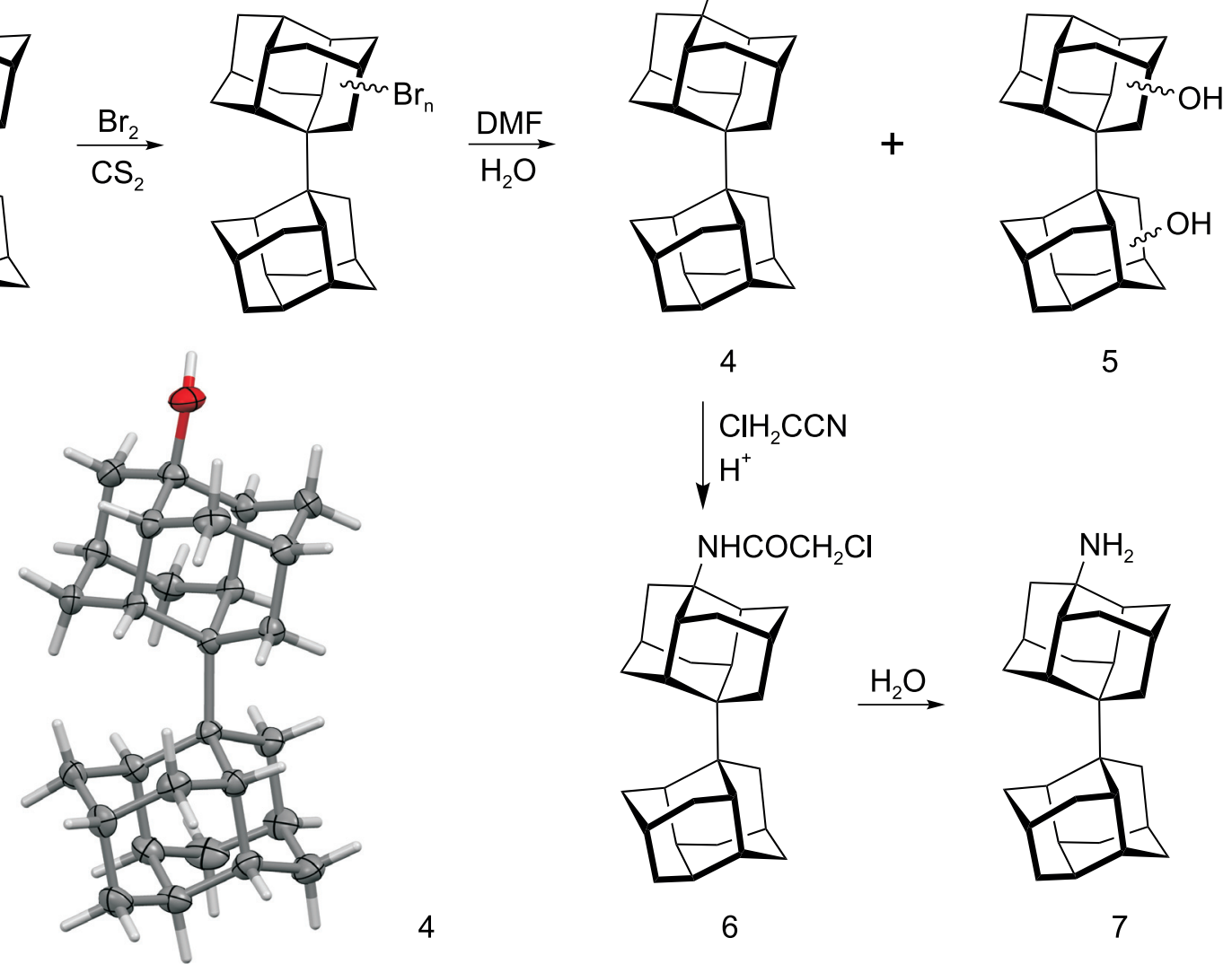

5

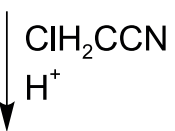

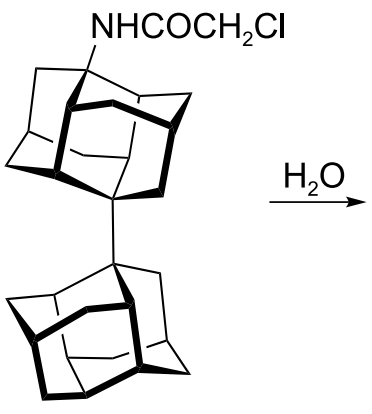

6

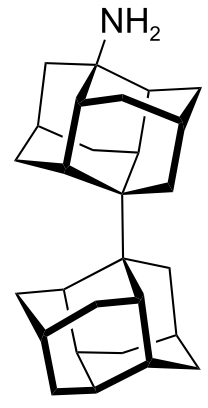

7

Fig. 3. Functionalization of 1,1'-bisdiamantane 1 and the molecular structure obtained by single crystal X-ray diffraction of monohydroxy derivative 4

layer was extracted with $3 \times 15 \mathrm{~mL}$ of $\mathrm{CHCl}_{3}$, the combined organic layers were dried over anhydrous $\mathrm{Na}_{2} \mathrm{SO}_{4}$ and evaporated. The resulting mixture of bromides (1.218 g) was dissolved in $75 \mathrm{~mL}$ of DMF, $3 \mathrm{~mL}$ of water was added, and the mixture was refluxed for $17 \mathrm{~h}$, cooled, diluted with $50 \mathrm{~mL}$ of water and filtered. Column chromatography of precipitate on silica gel (hexane-diethyl ether (10:1)) gave $0.191 \mathrm{~g}$ (19\%) of 1, $0.58 \mathrm{~g}(56 \%)$ of 6-hydroxy-1,1'-bisdiamantane 4 as a colorless solid and $0.135 \mathrm{~g} \mathrm{(10 \% )}$ of the mixture of diols.
6-Hydroxy-1,1'-bisdiamantane 4. M. p. $322-323^{\circ} \mathrm{C}$. Anal. Calcd. for $\mathrm{C}_{28} \mathrm{H}_{38} \mathrm{O}, \%$ : C 86.10, $\mathrm{H}$ 9.81. Found, \%: C 86.40, H 9.65. ${ }^{1} \mathrm{H}$ NMR ( $\left.600 \mathrm{MHz}, \mathrm{CDCl}_{3}\right), \delta$, ppm: 2.55 $(1 \mathrm{H}, \mathrm{s}), 2.33-2.45(2 \mathrm{H}, \mathrm{m}), 2.30(1 \mathrm{H}, \mathrm{s}), 2.17-2.27$ $(2 \mathrm{H}, \mathrm{m}), 2.05-2.15(4 \mathrm{H}, \mathrm{m}), 1.85-1.95(4 \mathrm{H}, \mathrm{m}), 1.80$ $(1 \mathrm{H}, \mathrm{s}), 1.55-1.77(14 \mathrm{H}, \mathrm{m}), 1.35-1.53(7 \mathrm{H}, \mathrm{m})$, $1.25-1.33(2 \mathrm{H}, \mathrm{m}) .{ }^{13} \mathrm{C}$ NMR $\left(150 \mathrm{MHz}, \mathrm{CDCl}_{3}\right), \delta$, ppm: $70.4(\mathrm{COH}), 47.2\left(\mathrm{CH}_{2}\right), 46.6(\mathrm{CH}), 46.3(\mathrm{CH}), 44.4$ $(\mathrm{CH}), 43.9(\mathrm{C}), 42.1(\mathrm{C}), 42.10(\mathrm{CH}), 41.6(\mathrm{CH}), 41.6$ $(\mathrm{CH}), 41.5(\mathrm{CH}), 39.5\left(\mathrm{CH}_{2}\right), 39.1(\mathrm{CH}), 38.9\left(\mathrm{CH}_{2}\right), 38.5$ $\left(\mathrm{CH}_{2}\right), 38.4(\mathrm{CH}), 38.3\left(\mathrm{CH}_{2}\right), 38.2\left(\mathrm{CH}_{2}\right), 36.1\left(\mathrm{CH}_{2}\right)$,
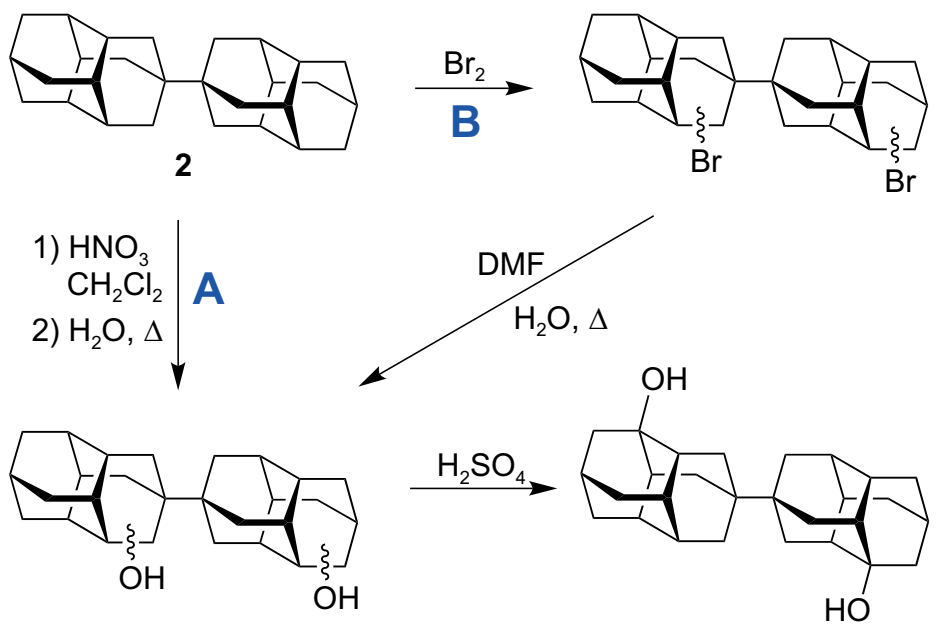

$8\left(60 \%{ }^{\mathrm{A}}, 73 \%^{\mathrm{B}}\right)$

Scheme 1. Functionalization of 4,4'-bisdiamantane 2 


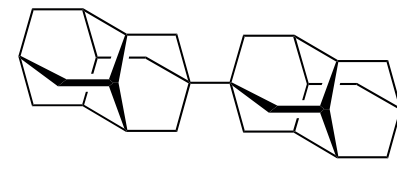

2

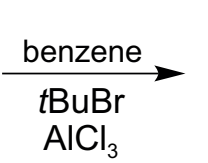

$\mathrm{AlCl}_{3}$

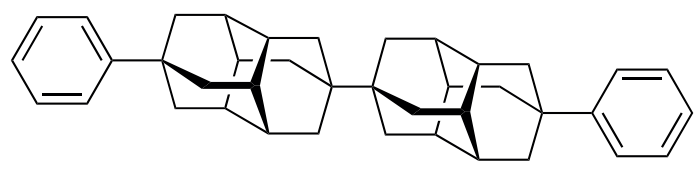

$9(47 \%)$

Scheme 2. The synthesis of 9,9'-diphenyl-4,4'-bisdiamantane 9

$35.5\left(\mathrm{CH}_{2}\right), 34.9\left(\mathrm{CH}_{2}\right), 34.3\left(\mathrm{CH}_{2}\right), 32.2\left(\mathrm{CH}_{2}\right), 31.9$ $\left(\mathrm{CH}_{2}\right), 30.0(\mathrm{CH}), 28.3(\mathrm{CH}), 27.1(\mathrm{CH}), 26.2(\mathrm{CH})$. MS-TOF+Na ${ }^{+}(\mathrm{m} / \mathrm{z})$ : calcd. for $\mathrm{C}_{28} \mathrm{H}_{38} \mathrm{ONa}$ 413.2820; found 413.2821 .

6-Chloroacetamido-1,1'-bisdiamantane 6. A mixture of $50 \mathrm{mg}(0.13 \mathrm{mmol})$ of 6-hydroxy-1,1'-bisdiamantane $4,0.8 \mathrm{~mL}$ of acetic acid, $0.3 \mathrm{~mL}$ of chloroacetonitrile and $0.2 \mathrm{~mL}$ of $\mathrm{H}_{2} \mathrm{SO}_{4}(96 \%)$ was stirred at room temperature for $20 \mathrm{~h}$, diluted with $5 \mathrm{~mL}$ of water and extracted with $3 \times 2 \mathrm{~mL} \mathrm{CHCl}_{3}$. The organic layers were combined, dried over anhydrous $\mathrm{Na}_{2} \mathrm{SO}_{4}$ and evaporated. Column chromatography of the residue on silica gel $\left(\mathrm{CH}_{2} \mathrm{Cl}_{2}\right.$-diethyl ether (3:1)) gave $55 \mathrm{mg}(92 \%)$ of 6 -chloroacetamido-1,1'-bisdiamantane 6 as a white solid.

M. p. $219-220^{\circ} \mathrm{C}$ (hexane). ${ }^{1} \mathrm{H}$ NMR $\left(600 \mathrm{MHz}, \mathrm{CDCl}_{3}\right)$, $\delta$, ppm: $6.4(1 \mathrm{H}, \mathrm{s}), 4.0(2 \mathrm{H}, \mathrm{s}), 2.5(1 \mathrm{H}, \mathrm{bs}), 2.25-2.45$ $(4 \mathrm{H}, \mathrm{m}), 2.20(1 \mathrm{H}, \mathrm{bs}), 2.05-2.15(5 \mathrm{H}, \mathrm{m}), 1.85-2.05$ $(8 \mathrm{H}, \mathrm{m}), 2.60-2.85(11 \mathrm{H}, \mathrm{m}), 2.40-2.60(7 \mathrm{H}, \mathrm{m})$. ${ }^{13} \mathrm{C}$ NMR (150 MHz, $\mathrm{CDCl}_{3}$ ), $\delta$, ppm: 164.2 (C=0), 56.5 (C), $44.4(\mathrm{C}), 43.8(\mathrm{C}), 43.1\left(\mathrm{CH}_{2}\right), 42.8(\mathrm{CH}), 42.3(\mathrm{CH})$, $42.2(\mathrm{CH}), 42.1\left(\mathrm{CH}_{2}\right), 41.4(\mathrm{CH}), 41.3(\mathrm{CH}), 40.8(\mathrm{CH})$, $39.1\left(\mathrm{CH}_{2}\right), 39.0(\mathrm{CH}), 38.4\left(\mathrm{CH}_{2}\right), 38.3\left(\mathrm{CH}_{2}\right), 38.2\left(\mathrm{CH}_{2}\right)$, $38.1(\mathrm{CH}), 35.9\left(\mathrm{CH}_{2}\right), 34.8\left(\mathrm{CH}_{2}\right), 34.7\left(\mathrm{CH}_{2}\right), 33.7\left(\mathrm{CH}_{2}\right)$, $32.3\left(\mathrm{CH}_{2}\right), 32.0\left(\mathrm{CH}_{2}\right), 27.9(\mathrm{CH}), 27.8(\mathrm{CH}), 26.5(\mathrm{CH})$, $25.8(\mathrm{CH})$. HR-MS (EI), m/z: calcd. for $\mathrm{C}_{30} \mathrm{H}_{40} \mathrm{ClNO}$ $465.280[\mathrm{M}]^{+}$; found 465.276 .

6-Amino-1,1'-bisdiamantane 7. A mixture of $50 \mathrm{mg}$ ( $0.11 \mathrm{mmol})$ of 6 -chloroacetamido-1,1'-bisdiamantane $\mathbf{6}$, $40 \mathrm{mg}$ of thiourea and $1.2 \mathrm{~mL}$ of ethyl alcohol was refluxed for $20 \mathrm{~h}$. The cooled reaction mixture was evaporated, the residue was dissolved in diethyl ether, and acidified with gaseous $\mathrm{HCl}$. Amine hydrochloride was filtered, dissolved in distilled water, alkalified with aq. $\mathrm{NaOH}$, and extracted with ethyl acetate $(3 \times 2 \mathrm{~mL})$. The combined organic layers were dried over $\mathrm{Na}_{2} \mathrm{SO}_{4}$ and concentrated in vacuo to yield $37 \mathrm{mg}$ (89\%) of 6-amino-1,1'-bisdiamantane 7 as a colorless solid.

M.p. $291-292^{\circ} \mathrm{C}$ (hexane). ${ }^{1} \mathrm{H} \mathrm{NMR}\left(600 \mathrm{MHz}, \mathrm{CDCl}_{3}\right)$, $\delta$, ppm: $2.45(1 \mathrm{H}, \mathrm{s}), 2.30-2.35(2 \mathrm{H}, \mathrm{m}), 2.25(1 \mathrm{H}, \mathrm{s})$, $2.05-2.15(4 \mathrm{H}, \mathrm{m}), 2.00(2 \mathrm{H}, \mathrm{s}), 1.80-1.87(4 \mathrm{H}, \mathrm{m})$, $1.75(1 \mathrm{H}, \mathrm{s}), 1.55-1.70(16 \mathrm{H}, \mathrm{m}), 1.53(1 \mathrm{H}, \mathrm{s}), 1.35-1.50$ $(7 \mathrm{H}, \mathrm{m}) \cdot{ }^{13} \mathrm{C} \mathrm{NMR}\left(150 \mathrm{MHz}, \mathrm{CDCl}_{3}\right), \delta, \mathrm{ppm}: 45.9\left(\mathrm{CNH}_{2}\right)$, $44.3(\mathrm{C}), 43.7(\mathrm{C}), 43.0(\mathrm{CH}), 41.4(\mathrm{CH}), 41.3(\mathrm{CH})$, $41.3(\mathrm{CH}), 41.0(\mathrm{CH}), 39.2\left(\mathrm{CH}_{2}\right), 39.0(\mathrm{CH}), 38.5\left(\mathrm{CH}_{2}\right)$, $38.4\left(\mathrm{CH}_{2}\right), 38.2\left(\mathrm{CH}_{2}\right), 38.1(\mathrm{CH}), 38.1\left(\mathrm{CH}_{2}\right), 35.8\left(\mathrm{CH}_{2}\right)$, $35.3\left(\mathrm{CH}_{2}\right), 34.7\left(\mathrm{CH}_{2}\right), 34.1\left(\mathrm{CH}_{2}\right), 32.0\left(\mathrm{CH}_{2}\right), 31.8\left(\mathrm{CH}_{2}\right)$, $28.4(\mathrm{CH}), 27.9(\mathrm{CH}), 26.7(\mathrm{CH}), 25.8(\mathrm{CH}) . \mathrm{HR}-\mathrm{MS}(\mathrm{EI}), \mathrm{m} / \mathrm{z}$ : 20 calcd. for $\mathrm{C}_{28} \mathrm{H}_{40} \mathrm{~N} 390.3080[\mathrm{M}+\mathrm{H}]^{+}$; found 390.3160 .

Photooxidation of 1,1'-bisdiamantane 1. A mixture of $250 \mathrm{mg}(0.67 \mathrm{mmol})$ of $\mathbf{1}, 1,2,4,5$-tetracyanobenzene (75 mg, $0.42 \mathrm{mmol}$ ) in $330 \mathrm{~mL}$ of acetonitrile was irradiated with a medium-pressure Hg-lamp in a quartz vessel for $8 \mathrm{~h}$. The GC-MS analysis of the reaction mixture revealed the presence of $98 \%$ of the unchanged starting compound 1 and $2 \%$ of 1 -acetamidodiamanantane identified based on the retention time and mass-spectrum using a standard sample independently prepared [33].

1,1'-Dihydroxy-4,4'-bisdiamantane 8. Method A. To the solution of $0.3 \mathrm{~g}(0.8 \mathrm{mmol})$ of $4,4^{\prime}$-bisdiamantane 2 in $0.16 \mathrm{~mL}$ of dichloromethane, dropwise $0.6 \mathrm{~mL}$ of $\mathrm{HNO}_{3}(100 \%)$ was added at $0^{\circ} \mathrm{C}$. The reaction mixture was stirred for $3 \mathrm{~h}$ at $0^{\circ} \mathrm{C}$ and for $15 \mathrm{~h}$ at room temperature, diluted with distilled water and refluxed for $15 \mathrm{~min}$. After cooling to room temperature the reaction mixture was extracted with $3 \times 5 \mathrm{~mL}$ of $\mathrm{CHCl}_{3}$. The combined extracts were dried over anhydrous $\mathrm{Na}_{2} \mathrm{SO}_{4}$ and evaporated to give $0.196 \mathrm{~g}$ of the mixture of alcohols.

Method B. To $0.2 \mathrm{~g}(0.53 \mathrm{mmol})$ of 4,4'-bisdiamantane 2, dropwise $2.1 \mathrm{~mL}$ of bromine was added at $0^{\circ} \mathrm{C}$ and stirred at room temperature for $3 \mathrm{~h}$. The reaction mixture was diluted with $50 \mathrm{~mL}$ of $\mathrm{CHCl}_{3}$, the excess of bromine was quenched with $\mathrm{Na}_{2} \mathrm{SO}_{3}$, the organic layer was washed with water and brine. The aqueous layer was extracted with $3 \times 15 \mathrm{~mL}$ of $\mathrm{CHCl}_{3}$, the organic layers were combined, dried over anhydrous $\mathrm{Na}_{2} \mathrm{SO}_{4}$ and evaporated. The residue was refluxed for $7 \mathrm{~h}$ in a mixture of $5 \mathrm{~mL} \mathrm{DMF}$ and $2 \mathrm{~mL}$ of water, cooled, diluted with $50 \mathrm{~mL}$ of water. Filtration and drying gave $0.16 \mathrm{~g}$ of the mixture of alcohols.

$0.17 \mathrm{~g}$ of the mixture of alcohols obtained via Methods $A$ or $B$ was gradually added while stirring to $36 \mathrm{~mL}$ of the concentrated $\mathrm{H}_{2} \mathrm{SO}_{4}$ cooled to $-4^{\circ} \mathrm{C}$. The reaction mixture was stirred for $20 \mathrm{~min}$ at room temperature and poured on ice, extracted with $3 \times 5 \mathrm{~mL}$ of $\mathrm{CCl}_{4}$, the combined organic extracts were washed with brine and dried over $\mathrm{Na}_{2} \mathrm{SO}_{4}$. The residue after evaporation was purified by column chromatography $\left(\mathrm{SiO}_{2}\right.$, hexane-ethyl acetate $\left.(4: 1)\right)$ to give $0.145 \mathrm{~g}$ (73\%) of 1,1'-dihydroxy-4,4'-bisdiamantane 8 as a white crystalline solid.

M. p. $240-241^{\circ} \mathrm{C} .{ }^{1} \mathrm{H}$ NMR $\left(600 \mathrm{MHz}, \mathrm{CDCl}_{3}\right), \delta$, ppm: 2.75-2.10 (4H, m), 2.00-1.93 (4H, m), 1.75-1.57 (8H, m), $1.52-1.43(13 \mathrm{H}, \mathrm{m}), 1.42-1.33(9 \mathrm{H}, \mathrm{m}) .{ }^{13} \mathrm{C}$ NMR $(150 \mathrm{MHz}$, 
$\left.\mathrm{CDCl}_{3}\right), \delta$, ppm: $71.2(\mathrm{C}), 44.4\left(\mathrm{CH}_{2}\right), 42.2(\mathrm{CH}), 39.8(\mathrm{CH})$, $39.1(\mathrm{C}), 37.2\left(\mathrm{CH}_{2}\right), 36.2(\mathrm{CH}), 35.5\left(\mathrm{CH}_{2}\right), 31.7\left(\mathrm{CH}_{2}\right)$, 24.9 (CH). MS (EI), m/z (I,\%): $186\left[\mathrm{M}-\mathrm{C}_{14} \mathrm{H}_{20} \mathrm{O}_{2}\right]^{+}(100)$, $203\left[\mathrm{M}-\mathrm{C}_{14} \mathrm{H}_{19} \mathrm{O}\right]^{+}(10), 406[\mathrm{M}]^{+}(1)$.

9,9'-Diphenyl-4,4'-bisdiamantane 9. A mixture of $0.2 \mathrm{~g}(0.53 \mathrm{mmol})$ of 4,4'-bisdiamantane $2,0.01 \mathrm{~g}$ $(0.075 \mathrm{mmol})$ of anhydrous $\mathrm{AlCl}_{3}, 1.2 \mathrm{~mL}$ of benzene and $0.15 \mathrm{~mL}$ of tert-butyl bromide was refluxed for $24 \mathrm{~h}$ while stirring. The reaction mixture was cooled, filtered, the precipitate was washed with ether and $0.1 \mathrm{M} \mathrm{HCl}$, dried in air at room temperature to a constant weight to give $0.13 \mathrm{~g}(47 \%)$ of 9,9'-diphenyl4,4'-bisdiamantane 9 as a white crystalline solid.

M. p. $309-310^{\circ} \mathrm{C} .{ }^{1} \mathrm{H}$ NMR $\left(600 \mathrm{MHz}, \mathrm{CDCl}_{3}\right)$, $\delta$, ppm: 7.30-7.00 (10H, m), $1.92-1.58(36 \mathrm{H}, \mathrm{m}) .{ }^{13} \mathrm{C}$ NMR (150 MHz, $\mathrm{CDCl}_{3}$ ), $\delta, \mathrm{ppm:} 128.6(\mathrm{C}), 128.5(\mathrm{CH})$, $125.9(\mathrm{CH}), 125.5(\mathrm{CH}), 43.9\left(\mathrm{CH}_{2}\right), 38.4(\mathrm{CH})$, $37.8(\mathrm{CH}), 36.2\left(\mathrm{CH}_{2}\right), 34.0$ (C), 30.7 (C). MS (EI), $\mathrm{m} / \mathrm{z}(\mathrm{I}, \%): 91\left[\mathrm{M}-\mathrm{C}_{33} \mathrm{H}_{38}\right]^{+}(75), 263\left[\mathrm{M}-\mathrm{C}_{20} \mathrm{H}_{23}\right]^{+}(100)$, $264\left[\mathrm{M}-\mathrm{C}_{20} \mathrm{H}_{22}\right]^{+}(85), 526[\mathrm{M}]^{+}$(1). HR-MS (EI), m/z: calcd. for $\mathrm{C}_{40} \mathrm{H}_{46} 526.360[\mathrm{M}]^{+}$; found 526.361 .

\section{Conclusions}

We studied the functionalization of $1,1^{\prime}$ - and 4,4'bisdiamantanes, whose bromination and nitroxylation reactions followed by hydrolysis gave medially substituted derivatives. The reactions with electrophiles led exclusively to the $\mathrm{C}-\mathrm{H}$ functionalization products and conserve the dimeric structure despite the presence of unusually long central $\mathrm{C}-\mathrm{C}$ bond in 1,1'-bisdiamantane. The bis-apical functionalization of $\mathbf{2}$ was achieved through the Friedel-Crafts arylation to give 9,9'-diphenyl-4,4'-bisdiamantane in moderate yield. The latter molecule can not only be considered as a building block for the construction of bis-apical diamondoid derivatives, but also for the preparation of extended diamantane-based molecular machines as it was previously demonstrated for 4,9-diphenyldiamantane [32].

Conflict of interests: the authors have no conflict of interests to declare.

\section{References}

1. Subramanian, K.; Wong, Y. M.; Kang, W. P.; Davidson, J. L.; Choi, B. K.; Howell, M. Nanocarbon field emission devices. Phys. Status Solidi A 2006, 203 (12), 3042-3048. https://doi.org/10.1002/pssa.200671104.

2. Shenderova, O. A.; Zhirnov, V. V.; Brenner, D. W. Carbon Nanostructures. Crit. Rev. Solid State Mater. Sci. 2002, 27 (3-4), 227-356. https://doi. org/10.1080/10408430208500497.

3. Cerofolini, G. F.; Arena, G.; Camalleri, M.; Galati, C.; Reina, S.; Renna, L.; Mascolo, D.; Nosik, V. Strategies for nanoelectronics. Microelectron. Eng. 2005, 81 (2), 405-419. https://doi.org/10.1016/j.mee.2005.03.041.

4. Achatz, P.; Garrido, J. A.; Williams, O. A.; Bruno, P.; Gruen, D. M.; Kromka, A.; Steinmüller, D.; Stutzmann, M. Structural, optical, and electronic properties of nanocrystalline and ultrananocrystalline diamond thin films. Phys. Status Solidi A 2007, 204 (9), 2874-2880. https://doi.org/10.1002/ pssa.200776337.

5. Kuznetsov, V. L.; Chuvilin, A. L.; Moroz, E. M.; Kolomiichuk, V. N.; Shaikhutdinov, S. K.; Butenko, Y. V.; Mal'kov, I. Y. Effect of explosion conditions on the structure of detonation soots: Ultradisperse diamond and onion carbon. Carbon 1994, 32 (5), 873-882. https://doi.org/10.1016/00086223(94)90044-2.

6. Schrand, A. M.; Hens, S. A. C.; Shenderova, O. A. Nanodiamond Particles: Properties and Perspectives for Bioapplications. Crit. Rev. Solid State Mater. Sci. 2009, 34 (1-2), 18-74. https://doi.org/10.1080/10408430902831987.

7. Drummond, N. D. Diamondoids display their potential. Nat. Nanotechnol. 2007, 2 (8), 462-463. https://doi.org/10.1038/nnano.2007.232.

8. Yang, W. L.; Fabbri, J. D.; Willey, T. M.; Lee, J. R. I.; Dahl, J. E.; Carlson, R. M. K.; Schreiner, P. R.; Fokin, A. A.; Tkachenko, B. A.; Fokina, N. A.; Meevasana, W.; Mannella, N.; Tanaka, K.; Zhou, X. J.; van Buuren, T.; Kelly, M. A.; Hussain, Z.; Melosh, N. A.; Shen, Z.-X. Monochromatic Electron Photoemission from Diamondoid Monolayers. Science 2007, 316 (5830), 1460-1462. https://doi.org/10.1126/science.1141811.

9. Dahl, J. E.; Liu, S. G.; Carlson, R. M. K. Isolation and Structure of Higher Diamondoids, Nanometer-Sized Diamond Molecules. Science 2003, 299 (5603), 96-99. https://doi.org/10.1126/science.1078239.

10. Dahl, J. E. P.; Moldowan, J. M.; Peakman, T. M.; Clardy, J. C.; Lobkovsky, E.; Olmstead, M. M.; May, P. W.; Davis, T. J.; Steeds, J. W.; Peters, K. E.; Pepper, A.; Ekuan, A.; Carlson, R. M. K. Isolation and Structural Proof of the Large Diamond Molecule, Cyclohexamantane $\left(\mathrm{C}_{26} \mathrm{H}_{30}\right)$. Angew. Chem., Int. Ed. 2003, 42 (18), 2040-2044. https://doi.org/10.1002/anie.200250794.

11. Zimmermann, T.; Richter, R.; Knecht, A.; Fokin, A. A.; Koso, T. V.; Chernish, L. V.; Gunchenko, P. A.; Schreiner, P. R.; Möller, T.; Rander, T. Exploring covalently bonded diamondoid particles with valence photoelectron spectroscopy. J. Chem. Phys. 2013, 139 (8), 084310. https://doi.org/ $10.1063 / 1.4818994$

12. Schreiner, P. R.; Chernish, L. V.; Gunchenko, P. A.; Tikhonchuk, E. Y.; Hausmann, H.; Serafin, M.; Schlecht, S.; Dahl, J. E. P.; Carlson, R. M. K.; Fokin, A. A. Overcoming lability of extremely long alkane carbon-carbon bonds through dispersion forces. Nature 2011, 477 (7364), 308-311. https://doi. org/10.1038/nature10367.

13. Fokin, A. A.; Chernish, L. V.; Gunchenko, P. A.; Tikhonchuk, E. Y.; Hausmann, H.; Serafin, M.; Dahl, J. E. P.; Carlson, R. M. K.; Schreiner, P. R. Stable Alkanes Containing Very Long Carbon-Carbon Bonds. J. Am. Chem. Soc. 2012, 134 (33), 13641-13650. https://doi.org/10.1021/ja302258q.

14. Reinhardt, H. F. Biadamantane and Some of Its Derivatives. J. Org. Chem. 1962, 27 (9), 3258-3261. https://doi.org/10.1021/jo01056a066.

15. Ulman, A. Formation and Structure of Self-Assembled Monolayers. Chem. Rev. 1996, 96 (4), 1533-1554. https://doi.org/10.1021/cr9502357.

16. Dameron, A. A.; Charles, L. F.; Weiss, P. S. Structures and Displacement of 1-Adamantanethiol Self-Assembled Monolayers on Au\{111\}. J. Am. Chem. Soc. 2005, 127 (24), 8697-8704. https://doi.org/10.1021/ja042621o.

17. Kitagawa, T.; Idomoto, Y.; Matsubara, H.; Hobara, D.; Kakiuchi, T.; Okazaki, T.; Komatsu, K. Rigid Molecular Tripod with an Adamantane Framework and Thiol Legs. Synthesis and Observation of an Ordered Monolayer on Au(111). J. Org. Chem. 2006, 71 (4), 1362-1369. https://doi.org/ 10.1021/jo051863j.

18. Lopatina, Y. Y.; Vorobyova, V. I.; Fokin, A. A.; Schreiner, P. R.; Marchenko, A. A.; Zhuk, T. S. Structures and Dynamics in Thiolated Diamantane Derivative Monolayers. J. Phys. Chem. C 2019, 123 (45), 27477-27482. https://doi.org/10.1021/acs.jpcc.9b06625.

19. Kobayashi, S.; Matsuzawa, T.; Matsuoka, S.-i.; Tajima, H.; Ishizone, T. Living Anionic Polymerizations of 4-(1-Adamantyl)styrene and 3-(4-Vinylphenyl)1,1'-biadamantane. Macromolecules 2006, 39 (18), 5979-5986. https://doi.org/10.1021/ma060977+.

20. Chernish, L. V.; Gunchenko, P. A.; Barabash, A. V.; Goreslavets, V. C.; Yurchenko, A. G.; Fokin, A. A. Selective synthesis of mono-derivatives of 1,1-diadamantane. J. Org. Pharm. Chem. 2008, 6, 48-51. 
21. Barabash, A. V.; Butova, E. D.; Kanyuk, I. M.; Schreiner, P. R.; Fokin, A. A. Beyond the Corey Reaction II: Dimethylenation of Sterically Congested Ketones. J. Org. Chem. 2014, 79 (21), 10669-10673. https://doi.org/10.1021/jo502021x.

22. Fokin, A. A.; Zhuk, T. S.; Blomeyer, S.; Pérez, C.; Chernish, L. V.; Pashenko, A. E.; Antony, J.; Vishnevskiy, Y. V.; Berger, R. J. F.; Grimme, S.; Logemann, C.; Schnell, M.; Mitzel, N. W.; Schreiner, P. R. Intramolecular London Dispersion Interaction Effects on Gas-Phase and Solid-State Structures of Diamondoid Dimers. J. Am. Chem. Soc. 2017, 139 (46), 16696-16707. https://doi.org/10.1021/jacs.7b07884.

23. Frisch, M. J. T.; Trucks, G. W.; Schlegel, H. B.; Scuseria, G. E.; Robb, M. A.; Cheeseman, J. R.; Scalmani, G.; Barone, V.; Petersson, G. A.; Nakatsuji, H.; Li, X.; Caricato, M.; Marenich, A. V.; Bloino, J.; Janesko, B. G.; Gomperts, R.; Mennucci, B.; Hratchian, H. P.; Ortiz, J. V.; Izmaylov, A. F.; Sonnenberg, J. L.; WilliamsYoung, D.; Ding, F.; Lipparini, F.; Egidi, F.; Goings, J.; Peng, B.; Petrone, A.; Henderson, T.; Ranasinghe, D.; Zakrzewski, V. G.; Gao, J.; Rega, N.; Zheng, G.; Liang, W.; Hada, M.; Ehara, M.; Toyota, K.; Fukuda, R.; Hasegawa, J.; Ishida, M.; Nakajima, T.; Honda, Y.; Kitao, O.; Nakai, H.; Vreven, T.; Throssell, K.; Montgomery, J. A., Jr.; Peralta, J. E.; Ogliaro, F.; Bearpark, M. J.; Heyd, J. J.; Brothers, E. N.; Kudin, K. N.; Staroverov, V. N.; Keith, T. A.; Kobayashi, R.; Normand, J.; Raghavachari, K.; Rendell, A. P.; Burant, J. C.; Iyengar, S. S.; Tomasi, J.; Cossi, M.; Millam, J. M.; Klene, M.; Adamo, C.; Cammi, R.; Ochterski, J. W.; Martin, R. L.; Morokuma, K.; Farkas, O.; Foresman, J. B.; Fox, D. J. Gaussian 16, Revision B.01, Gaussian, Inc.: Wallingford CT, 2016.

24. Fokin, A. A.; Tkachenko, B. A.; Gunchenko, P. A.; Gusev, D. V.; Schreiner, P. R. Functionalized Nanodiamonds Part I. An Experimental Assessment of Diamantane and Computational Predictions for Higher Diamondoids. Chem. - Eur. J. 2005, 11 (23), 7091-7101. https://doi.org/10.1002/ chem.200500031.

25. Fokin, A. A.; Shubina, T. E.; Gunchenko, P. A.; Isaev, S. D.; Yurchenko, A. G.; Schreiner, P. R. H-Coupled Electron Transfer in Alkane C-H Activations with Halogen Electrophiles. J. Am. Chem. Soc. 2002, 124 (36), 10718-10727. https://doi.org/10.1021/ja0265512.

26. Osawa, E.; Engler, E. M.; Godleski, S. A.; Inamoto, Y.; Kent, G. J.; Kausch, M.; Schleyer, P. v. R. Application of force field calculations to organic chemistry. 10. Bridgehead reactivities of ethanoadamantane. Bromination and solvolysis of bromides. J. Org. Chem. 1980, 45 (6), 984-991. https://doi.org/ 10.1021/jo01294a014.

27. Fokin, A. A.; Peleshanko, S. A.; Gunchenko, P. A.; Gusev, D. V.; Schreiner, P. R. Hydrocarbon Activation with Cerium (IV) Ammonium Nitrate: Free Radical versus Oxidative Pathways. Eur. J. Org. Chem. 2000, 2000 (19), 3357-3362. https://doi.org/10.1002/1099-0690(200010)2000:19<3357::AIDEJOC3357>3.0.CO;2-R.

28. Jirgensons, A.; Kauss, V.; Kalvinsh, I.; Gold, M. R. A Practical Synthesis of tert-Alkylamines via the Ritter Reaction with Chloroacetonitrile. Synthesis 2000, 2000 (12), 1709-1712. https://doi.org/10.1055/s-2000-8208.

29. Klimochkin, Y. N.; Abramov, O. V.; Moiseev, I. K.; Vologin, M. F.; Leonova, M. V.; Bagrii, E. I. Reactivity of cage hydrocarbons in the nitroxylation reaction. Pet. Chem. 2000, 40, 415-418.

30. Fokina, N. A.; Tkachenko, B. A.; Merz, A.; Serafin, M.; Dahl, J. E. P.; Carlson, R. M. K.; Fokin, A. A.; Schreiner, P. R. Hydroxy Derivatives of Diamantane, Triamantane, and [121]Tetramantane: Selective Preparation of Bis-Apical Derivatives. Eur. J. Org. Chem. 2007, 2007 (28), 4738-4745. https:// doi.org/10.1002/ejoc.200700378.

31. Pannier, N.; Maison, W. Rigid $C_{3}$-Symmetric Scaffolds Based on Adamantane. Eur. J. Org. Chem. 2008, 2008 (7), 1278-1284. https://doi.org/ 10.1002/ejoc.200701003.

32. Karlen, S. D.; Ortiz, R.; Chapman, O. L.; Garcia-Garibay, M. A. Effects of Rotational Symmetry Order on the Solid State Dynamics of Phenylene and Diamantane Rotators. J. Am. Chem. Soc. 2005, 127 (18), 6554-6555. https://doi.org/10.1021/ja042512+.

33. Gund, T. M.; Nomura, M.; Williams, V. Z.; Schleyer, P. v. R.; Hoogzand, C. The functionalization of diamantane (congressane). Tetrahedron Lett. 1970, 11 (56), 4875-4878. https://doi.org/10.1016/S0040-4039(00)99732-6. 